INSTITUTE FOR SOCIAL AND ECONOMIC RESEARCH AND POLICY Columbia UNIVERSITY IN THE City OF NEW YORK

\title{
PARENTAL WEALTH EFFECTS ON LIVING STANDARDS AND ASSET HOLDINGS: RESULTS FROM CHILE
}

\author{
Florencia Torche \\ Department of Sociology, Queens College, CUNY \\ Center for the Study of Wealth and Inequality \\ Institute for Social and Economic Research and Policy \\ Columbia University \\ Seymour Spilerman \\ Center for the Study of Wealth and Inequality \\ Institute for Social and Economic Research and Policy \\ Columbia University
}

November 2004

ISERP WORKING PAPER 04-06 


\section{INSTITUTE FOR Social AND ECONOMIC RESEARCH AND POLICY \\ COLUMBIA UNIVERSITY \\ WORKING PAPERS}

\section{PARENTAL WEALTH EFFECTS ON LIVING STANDARDS AND ASSET HOLDINGS: RESULTS FROM CHILE*}

To Appear in Ed Wolff (ed.) International Perspectives on Household Wealth, Cheltenham, UK: Edward Elgar. 2005.

Florencia Torche Queens College, CUNY

Center for the Study of Wealth and Inequality

Institute for Social and Economic Research and Policy

Columbia University

Seymour Spilerman

Center for the Study of Wealth and Inequality

Institute for Social and Economic Research and Policy

Columbia University

November 2004

ISERP WORKING PAPER 04-06 
* This research was supported by Ford Foundation grant No.1010-2002 to the Center for the Study of Wealth and Inequality, Columbia University. We would like to thank Mitali Das for her advise on statistical issues. The conclusions are the sole responsibility of the authors.

\section{INTRODUCTION}

This paper examines aspects of the replication of inequality across generations and attempts to assess the extent to which parental resources influence the life chances and living standards of adult children. We expect household wealth to be a critical matter, especially in a society in which there is a weak public safety net or in which the credit market is inefficient. In the former case, families need to self-insure--accumulate savings to smooth consumption expenditures over periods of income fluctuation, such as might result from illness or job loss. In the latter case, financial wealth is necessary in order to finance large expenditure items (e.g., a home, a new business) or to provide collateral in seeking a bank loan for such an expenditure.

These considerations can be especially relevant to the welfare of children and young adults. In the absence of public support programs, poor families may have difficulty keeping children in school, especially teen-age children, and forgoing the earnings that would otherwise be brought to the household. Such calculations, it is recognized, are responsible for the high drop out rate from middle school, noted for less developed countries (Moser 1998). Similarly, substantial costs are often involved in establishing a new household, which can pose a major burden for a young couple that has had little time in which to accumulate savings (Spilerman 2004). In each case, parental assets can play a critical role in advancing the life chances and economic well-being of offspring.

If parental resources are important to the financial welfare and living standards of children, there remains a matter of the mechanics of the transmission process. This issue entails, first of all, a consideration of parental decision making regarding the amount to invest 
in a child's educational attainment versus providing assistance in the form of gifts (Becker 1981). A second consideration involves the pattern of allocation of direct transfers over the life course--both in terms of timing and purpose of the transfer: whether for the purchase of critical household items, or at times of financial crisis, or as regular on-going assistance. There is also the related matter of the contribution of asset holdingss to living standards. Indeed, we might have less interest in the wealth distribution of a country if most families can live reasonably well from earnings; if household wealth, for example, accounts for the disparity between driving a Chevrolet versus a BMW, rather than the gap between owning and not owning a vehicle.

A consideration of the impact of parental wealth on the living standards of offspring requires an examination of direct and indirect effects. Following Becker (1981), parental wealth can influence living standards through investments in children's education, permitting more years of attendance or enrollment in better quality schools and consequently higher income, or through direct transfers of financial and material assets. Our focus in this paper, however, departs from Becker's concern with parental decision-making in that we seek to assess the contribution of the different modes of parental transfer (educational investments vs. direct assistance) to aspects of a family's well-being. Thus, we are interested in which dimensions of the family's economic well-being are financed from their labor market income, and possibly reflect parental investments in education, and which are supported by direct transfers of resources.

These matters may have very different resolutions in developed and in less developed countries, in nations with a comprehensive public welfare system and in countries with weak public service programs, since patterns of parental assistance are deeply influenced by the availability of public support programs as well as by other institutional arrangements (Kohli 
2004, Attias-Donfut and Wolff 2000, Spilerman 2004). In the present paper we examine the noted issues in Chile, a less-developed country, one that in recent years has experienced an extensive privatization of its public social service programs. Chile is of interest both as a case study in the organization of parental transfers in that reasonably good data are available on the topic, and as a setting in which considerable parental assistance is required for the successful establishment of the new generation.

In an earlier paper (Spilerman and Torche 2004) parental resource effects were addressed from the perspective of living standard potential, essentially a consideration of their impact on measures of the household income and wealth stock of offspring. One finding was that parental wealth influences household income largely through its impact on educational attainment. However the educational system in Chile is broadly inclusive and was found not to be merely a conduit for the transmission of parental advantage. Indeed, the addition of the respondent's educational attainment to an earnings or to a household income equation contributed substantially to the variance explained by the measures of parental wealth and parental background. This was not the case, however, with respect to the determination of household wealth. In this instance there was strong evidence of the importance of direct transfers of parental resources, with little indication of a possibility that families in Chile accumulate net worth through educational attainment and savings from earnings.

In the present paper we continue to explore the relation between parental wealth and economic well-being, though we move from an analysis of living standard potential--a measure of capacity based on income and wealth--to an examination of realized living standards, as evidenced by the consumption behavior of families. The paper is divided into four sections. In the first, we describe the Chilean setting, compare it with the United States, and discuss the empirical association between parental wealth and different dimensions of adult children's 
economic well-being. Not surprisingly, we note that the rate of asset ownership tends to be lower in Chile and there is a greater tendency to asset concentration at high income levels. There is one noteworthy exception: homeownership in Chile is rather evenly dispersed among the income levels, a theme that is developed later in the paper.

The second section addresses the impact of parental wealth on two broad dimensions of the economic well-being of adult children, namely living standard (as expressed by consumption level) and asset ownership. This analysis reveals a consistent pattern: Parental wealth has a positive impact on each consumption measure, an effect that is net of other parental attributes. This effect is largely indirect, operating through the parental contribution to child's education and labor market earnings. In comparison, a similar analysis of the impact of parental wealth on the ownership of different asset types (with the exception of home residence) suggests a direct transmission of parental resources. Section three presents a structural equation model in which the two dimensions of economic well-being--consumption level and assets ownership--are formulated as unobserved constructs, with the prior measures now introduced as indicator variables. The use of latent constructs with multiple indicators mitigates the confounding of living standard (a hierarchical measure) with life style choice (a mix of consumption expenditures).

The final empirical section examines the particular status of homeownership in Chile from the perspective of time to ownership and home value. Departing from the pattern noted for the other asset types--and in contrast with findings from the U.S. and Western Europe (e.g., Engelhardt and Mayer 1994; Mulder and Smits 1999; Guiso and Jappelli 1999)--we find that parental resources have little impact on the waiting time from marriage to ownership. The explanation for this is found in the housing policy implemented by the Chilean government since the 1960s, which has largely detached access to residential ownership from family 
resources. Yet, while parental resources have little effect on the waiting time to ownership, they do retain a substantial impact on home value.

\section{ASSET OWNERSHIP IN CHILE}

Even though Chile has made significant economic progress in the last three decades, the level of economic well-being is far from that of most industrialized countries. Per-capita income is $\$ 4,890$, which compares to $\$ 30,740$ in the U.S. (World Bank 2000a). Income inequality is extremely high, as indicated by the Gini coefficient which reaches 56.5 , compared to 40.8 in the U.S. (World Bank 2000b). Furthermore, the pattern of Chilean inequality is characterized by a high concentration in the top decile and relatively less inequality across the rest of the income distribution (Torche 2003). There are no available estimates of the wealth distribution for Chile, but low per capita income and high income inequality suggest a high wealth concentration as well, which likely means that a large proportion of the population has very modest wealth holdings. In this context it is worth asking whether parental wealth has an impact on children's outcomes in the broad population, not merely among the wealthy. If even modest parental resources can be shown to be consequential for living standards, it becomes important to explore how the various transmission mechanisms--e.g., direct financial assistance, investments in children's human capital--are used by parents to pass advantage to the next generation.

To put the wealth holdings of the Chilean population in context, we present in Table 1 information on the ownership of several asset types and the distribution of ownership by income level in both Chile and the U.S.. The Chilean data come from the 2003 Survey of Intergenerational Financial Linkages in Chile (IFLC), a nationally representative household survey; the U.S. data are from the 1998 Survey of Consumer Finances (SCF). The asset types are primary residence, financial assets, business equity, small residential property, commercial 
real estate and vehicle ownership. We lack estimates of the financial value of these assets in Chilean households or of the proportion of net worth accounted for by the assets; in the U.S. according to the SCF they comprise $70.3 \%$ of total family wealth ${ }^{1}$ (Kennickell et.al. 2000). We do, however, have data for the two countries on the rate of ownership of each asset type and on their distributions by income level.

\section{TABLE 1 ABOUT HERE}

From Table 1 it is evident that financial holdings (stocks, bonds, mutual funds) are the most scarce asset in Chile, with ownership by only 3.6 percent of households, as opposed to 40 percent in the U.S. The ownership rate ranges from almost zero for the lowest income group in Chile to some 22 percent in the highest category. Note that while the increase in the rate is fairly linear in the U.S., in Chile there is a sharp gap between the top decile and the rest of the income categories. This gap is consistent with the pattern of economic inequality in the country, which is characterized by high concentration in the very top percentiles (Torche 2003).

Real estate ownership (farm, land, commercial and rental property, and other types of nonresidential property) averages 6.4 percent in the Chilean population, with the rate of ownership increasing from some 3 percent to 25 percent across the income range. The distribution is quite similar to that found in the U.S., a surprising finding given that Chile is poorer and more unequal. A possible explanation relates to the high prevalence of land ownership in Chile, often consisting of small plots. The findings for residential property (second residence, vacation home, etc.) are also much the same in the two countries. Observe, however, that in the case of each of these asset types the gap between the highest decile and the

\footnotetext{
${ }^{1}$ Omitted from the wealth estimates are CDs, retirement accounts, the cash value of life insurance, managed assets, and other (non-specified) financial and material assets. These
} 
immediately lower income category is considerably greater in Chile--further testimony to the concentration of economic resources.

With an ownership rate of 17 percent in Chile and 12 percent in the U.S., business equity is the one asset that is more prevalent in Chile. The distribution is relatively similar in the two countries, showing a monotonic, almost linear, increase across the income categories. While we cannot examine the value of business equity with the Chilean data, the high prevalence of small informal enterprises in Chile--peddler stands and homefront stores-suggests that the value of business equity is quite modest for most households that report this asset (Wormald and Rozas 1996).

In contrast, the rate of vehicle ownership is much lower in Chile--35 percent versus 83 percent in the U.S. Moreover, the distributions across income groups are strikingly different, especially at the low end of the scale. In the U.S., there is little variation beyond the second quintile, suggesting that by this income level most families who wish to own are able to purchase a vehicle; in short, the ownership decision is a lifestyle choice. In Chile, in contrast, the rate remains low until the highest quintile, suggesting a strong financial constraint on vehicle ownership.

The most interesting difference between the countries in pattern of asset ownership concerns primary residences. While the average rate is comparable in the two countries-$67.5 \%$ in Chile, $66.3 \%$ in the U.S.--the distributions across income categories are quite disparate; indeed, they are the reverse of the vehicle ownership pattern. In the U.S., the trend is one of a linear increase with income level, beginning with an ownership rate of some $40 \%$ for the lowest category. In comparison, in Chile, some $65 \%$ in the bottom group are homeowners, with little change in the rate as one moves to higher categories.

categories are omitted from the U.S. data because they lack a counterpart in the Chilean survey. 
The conspicuous difference between the two countries in the association of home ownership with income derives from the particular institutional arrangements in Chile. Since 1964, with the coming to power of a progressive Christian-Democratic government, a widespread redistribution program was instituted to respond to the sharp inequalities in the country and the growing urban unrest as a consequence of migration from the countryside. One dimension of the redistributive program was a policy of housing construction. This policy addressed the 'housing deficit' by providing homeownership access to the poor; however, the government's efforts were not enough to satisfy the growing demand of rural migrants, giving rise to illegal occupation of unused plots. As a consequence, a significant proportion of the poor became homeowners, either through the government programs or by means of illegal occupation (Departamento de Estudios MINVU 2004). Access to homeownership through illegal occupation became more frequent during the subsequent Socialist administration, in power between 1970 and 1973.

The overthrown of the Socialist government and emergence of a military regime in 1973 radically redefined the State housing policy. Illegal access was eliminated (though many existing homes with questionable title were legalized by the government), and a new marketbased strategy was implemented. This strategy included deregulation of the land market, private participation in construction via contracting, and targeted demand-based housing subsidies--'housing voucher programs' (Pardo 2000, Rojas 1999). An important element of continuity was the focus on homeownership, as opposed to rental access, as a housing solution for the poor (Departamento de Estudios MINVU 2004).

Housing subsidies were significantly expanded during the 1990s, providing home ownership access for hundreds of thousands of lower and middle class families (Departamento de Estudios MINVU 2004). The provided residences tend to be located in the urban periphery, 
where land is cheaper, and to be of low market value. All government subsidy programs require a small contribution from the recipient and are explicitly targeted toward the poor. Selection is based on a point system keyed to an extensive list of family characteristics, including waiting time, family income, and family size (Rojas 1999). Currently, more than fifty percent of the households in three lowest quintiles have become home-owners through the State program (Mideplan 2000). An international comparison is illustrative: the urban homeownership rate in Chile is one of the highest of the world, with only Singapore, Mexico, Pakistan, and Israel having higher rates (World Bank 1993; Spilerman 2004). Because the government strategy is to provide housing solutions to the poor through ownership instead of subsidized rentals, the average home price-to-income ratio for Chile is one of the lowest in the world. In contrast, the rent-to-income ratio is quite high, surpassed only by Korea, Mexico, and Singapore (Cummings and Dipasquale 2002).

Because of these institutional arrangements most Chilean families can become homeowners if they queue for the State subsidy. This equalization in access to home ownership contrasts with a sharp segmentation by income class in the value of owned homes. Table 2 reports the value of primary residences by income group for Chile and the U.S. The first two columns present values in local currency (U.S. dollars and Chilean pesos respectively); the two last columns report the figures as a percentage of home value in the lowest income category. In contrast with the flatness in the response of the ownership rate to household income in Chile (Table 1), home value increases with income level, much as in the U.S., though with a sharp jump at the highest income group. Thus, even though access to home ownership is largely detached from family resources in Chile, this is hardly the case with respect to home value. 


\section{TABLE 2 ABOUT HERE}

The tenancy pattern in Chile differs from the U.S. in another way. In the U.S. the clear alternative to homeownership is rental status (Table 1). In Chile, however, a greater proportion of the non-ownership population resides with parents or relatives (the "other" category in Table 1) than rents housing. The disparity is especially pronounced in the two lowest income quintiles--in which some $25 \%$ of the population lives with a relative (or in a non-standard tenure arrangement) versus $11 \%$ that rent. Residing with a parent, which accounts for the majority in this category, is a form of parental assistance that is much less utilized in the U.S.

There are three conclusions from this section. First, as expected from the differences in level of economic development in the two countries, the proportion of households that own some of the noted assets is significantly lower in Chile for most asset categories; nonetheless, asset ownership in Chile is not limited to the elite. Second, the distribution of asset holdings across income groups is very unequal, characterized by a substantial gap between the top income decile and the prior categories, which parallels the high concentration of financial and material resources in the population. Third, the distribution of home ownership departs from the pattern of the other asset types and is strikingly different from the ownership pattern in the U.S., in that even the very poor have a high rate of access to residence ownership.

\section{PARENTAL WEALTH AND CHILDREN'S OUTCOMES}

Descriptive statistics and analytic strategy. In this paper we investigate the contribution of parental asset holdings to children's living standards, with particular consideration of the transmission mechanism--whether parental investments in education or direct transfers of 
financial and material resources. The data used in the study come from the 2003 Survey of Intergenerational Financial Linkages in Chile (IFLC), conducted by Spilerman and Torche. The IFLS survey employed a nationally representative, multistage stratified sample of 4,408 Chilean households ${ }^{2}$. Respondents were male household heads or their wives/ partners. Information was collected about household resources and income, respondent's background and work experience, and spouse or partner's background and work experience. Considerable detail was sought about the asset holdings of the respondent, of his or her parents, and of the spouse/partners' parents.

In Table 3 we present descriptive statistics of the association between parental wealth and several measures of the economic well-being of adult children. The measures in the table cover two broad dimensions of well-being: consumption level and asset ownership. "Parental wealth" refers to the resource holdings of both sets of parents of the couple, measured when respondent and spouse/partner was each in his or her teen years. It is not possible to ask respondents about the value of parental holdings at that early time point, due to their limited knowledge about parental resources in past decades and to fluctuations in the inflation rate. Our strategy, consequently, was to inquire about the ownership of different kinds of parental assets: business equity, real estate, residential property, and financial assets (stocks, bonds, mutual funds); an approach to wealth measurement whose validity is supported by Sahn and Stifel (2003). The parental wealth measure is formulated as the sum of Z-scores from a count of the different asset types, with the scores combined from both sets of parents.

\footnotetext{
${ }^{2}$ The sampling strategy included three stages. First, 87 Primary Sampling Units (counties) were selected. Blocks within the PSUs were then selected, and finally households within blocks were chosen. Counties were stratified by size (less than 20,000;20,000-100,000;100,000-200,000; more than 200,000 inhabitants); and geographical zone (North, Center, South). Optimal allocation was used to increase efficiency (Lohr 1999) by including all PSUs in the large size
} 


\section{TABLE 3 ABOUT HERE}

The entries reveal a strong association between the parental wealth measure and the economic well-being of adult children. The score for each consumption item increases substantially as one moves from low to high levels of parental wealth; the same is true for the ownership rate of each asset type. The only exception is the rate of home ownership (row 9), which is not responsive to parental wealth. This singular pattern is associated with the detachment of home ownership from financial resources, as detailed in the previous section. The three last rows of the table refer to several determinants of consumption level and asset ownership; in particular, respondent's education, occupational status and household earnings, which are presumed to function as intervening variables, transmitting the parental advantage. Not surprisingly, the measures are also responsive to parental wealth. With these results we turn to two related questions. First, whether the beneficial impact of parental advantage operates through children's human capital and income, or directly through transfers of

resources. Second, how this general assessment of the path of parental transmission differs according to the particular aspect of economic well being that is under consideration.

To address these questions, we undertake a multivariate analysis of the effects of parental wealth on the different facets of family economic status. One caveat with regard to the data: While the conceptual argument emphasizes the role of parental assistance and intergenerational transfers, our analysis is limited to the impact of parental assets, as summarized by the parental wealth measure. While a transfer process is presumed to account

stratum (more than 200,000 inhabitants) in the sample. The fieldwork was conducted between April and June 2003 and consisted of face-to-face interviews in the respondent's household. 
for the parental effects on economic well-being, the details of the transmission process are not delineated in this study.

We distinguish between two dimensions of economic well-being: consumption level--a proxy for the couple's standard of living--and asset ownership, a household wealth indicator. The first is measured by the following items: vehicle ownership ${ }^{3}$, consumer durables ownership, use of domestic service, and a subjective standard of living indicator. The second dimension covers the following asset types: financial instruments (stocks, bonds, mutual funds), investment real estate, business equity, and residential property (other than primary residence). The parental resource effects were estimated individually for each of the consumption and asset items as dependent variables, to ascertain whether the path of transmission varies with the outcome type.

The unit of analysis in the regression models is the married or cohabitating couple. The models include measures of three kinds of parental resources: father's years of schooling, father's occupational status, and parental wealth. Father's occupational status--a proxy for permanent income--is coded in terms of the International Socioeconomic Index ISEI (Ganzeboom et. al. 1992). Parental wealth is measured as the sum of the standardized values of four dichotomous variables representing ownership of the differrent asset types: financial, land and investment real estate, residential property, and business equity. The parental resources terms were computed separately for each member of the couple to ascertain whether, possibly, there is a differential contribution from the holdings of parents of the male or the female

\footnotetext{
${ }^{3}$ Although the value of vehicles is a component of family wealth, our analytical formulation treats vehicles as a consumption item. The reason is that, unlike the other asset types, vehicles quickly depreciate in financial value though their "use value" for a household can remain high (Wolff 2001).
} 
partner. All parental resource terms refer to the period when respondent and partner were in their teen years.

Other variables included in the analysis are measures of the human capital of the couple (years of schooling by husband and wife) and monthly household income from labor market activity (in Chilean Pesos). We emphasize labor market income, as distinct from total household income, because the latter includes income that derives from parental asset transfers, whereas our intent is to differentiate between parental effects linked to investments in human capital, and those tied to direct assistance. Controls were also introduced for age of husband at marriage/cohabitation, for number of years in current union, and an indicator term for whether either partner had a previous marriage or cohabitation. Husband's age at marriage/cohabitation and the term for duration of the union are indicators of two different processes: the accumulation of savings before marriage/cohabitation and subsequent savings by the couple; we expect each to be a function of the pertinent temporal variable and we view each as adding to a couple's capacity to finance its living standard expenditures. The impact of a prior marriage or cohabitation, in contrast, taps the possible depletion of resources associated with a marital rupture and should have a negative impact on asset ownership.

It is the case of that some of the parental variables have rates of missing data that approach 15\% (see Table A-1) and in a regression with several variables the proportion of observations with missing data can reach 25\%. Dropping cases with missing data is both inefficient and can lead to biased estimates. In order to retain these observations a multiple imputation procedure was used (Rubin 1987). Five complete data sets were created using the imputation software Amelia (Honaker et.al. 2002). The analysis was replicated with each data set; the parameter estimates and standard errors were then combined. This approach provides unbiased estimates, assuming that the data are missing at random (MAR). 
Our analytic strategy is the following. In order to assess the two paths of parental transmission--via investments in human capital and direct transfers of resources--we estimate two models of the impact of parental resources on each indicator of living standard and asset holdings. The first model reports the total effect of the parental resource terms, as measured by the coefficients in a reduced form model. The second adds the human capital terms for husband and wife, the couple's earnings, ${ }^{4}$ and the control variables, and is intended to assess the extent to which the initial parental effects are diminished by these terms--an indication of indirect parental transmissions operating through investments in human capital.

Parental wealth effects on consumption behavior. As noted we have four consumption measures. The results for the first, vehicle ownership, are presented in Table 4. Vehicle ownership is formulated as a dichotomous variable, coded 1 if the couple owns one or more vehicles; hence the entries in Table 4 are estimates from a logistic regression model.

\section{TABLE 4 ABOUT HERE}

The first column presents total effects of the parental background measures on the logodds of vehicle ownership. All the variables have positive effects, though parental education is significant only for husband's father. Occupational status, a proxy for parental permanent income, is positive and significant for both sets of parents. Of particular consequence for this study, both parental wealth terms have significant impacts on ownership of this consumption item, effects that are net of the other parental terms--the parental resource variables that typically have been considered in the status attainment literature (e.g., Blau and Duncan 1967;

\footnotetext{
${ }^{4}$ Alternatively, we could have used husband's and wife's occupational status instead of the couple's current earnings in order to smooth earnings fluctuations and capture permanent labor market income. Analyses carried out using the occupational status terms show that the results are not sensitive to this change in specification.
} 
Duncan, Featherman and Duncan 1972). To obtain a sense of the magnitude of the effects note that, for husband's father, a one-standard deviation increase in educational attainment-approximately five years of schooling--would raise the odds of vehicle ownership by 20 percent $\left(\mathrm{e}^{[.038][4.81]}\right)$, while a standard deviation shift in occupational status or in parental wealth translates, respectively, into changes of $33 \%$ and $17 \%$ in the odds of ownership.

The second model (column 2) adds terms for husband's and wife's educational attainments and for household labor market income, along with the controls. Not surprisingly, husband's education and household income have strong effects on vehicle ownership. Years of marriage also raises the odds; this term taps duration of resource accumulation, as well as the growth in husband's labor force experience.

A principal question for the study concerns whether the effects of the parental resources are direct or mediated by parental investments in the couple's human capital. This matter can be addressed by examining the change in the coefficients of the parental resource terms after respondent's and partner's human capital and the household income term are added to the model. From comparing equations 2 and 1 it is evident that the changes are considerable; all the parental terms that previously were significant are reduced to insignificance. (We view the now significant, but negative, term for wife's father's education as a sampling anomaly.) We therefore conclude that the parental resource effects operate through educational attainment and labor market earnings, and reflect the ability of parents with more resources to provide better education to their offspring, which is translated into higher labor market income and a greater consumption capacity.

Finally, though peripheral to the current study, our findings permit a tentative observation about the educational system. Note that the McFadden's pseudo- $\mathrm{R}^{2}$ in column 2 (.249) is almost three times its size in column 1 (.092). If the only avenue of access to 
education, better earnings, and a higher living standard (vehicle ownership narrowly in this equation) were through parental resources, the change in $\mathrm{R}^{2}$ from addition of the human capital and earnings terms would have been small. The observed, substantial increase indicates that education and labor market income not only serve as intervening variables, transmitting the parental resource effects, but have significant additional consequences; in short, access to schooling and income do not come solely from parental advantage. This finding suggests that government interventions in Chile over several decades to bolster educational attainment (see Spilerman and Torche [2004] for details), opening the possibility of schooling to poor families and encouraging enrollment by their children, may have served to weaken the linkage between parental resources and living standards, at least in regard to vehicle ownership.

Similar analyses were carried out with the other measures of children's living standard: use of domestic hired help, consumer durables ownership, and a subjective standard of living term. These variables were measured as follows. Domestic service is an ordinal variable and indexes whether the household had full time hired domestic help, part time help, or no domestic assistance. Consumer durables ownership was measured as the sum of the standardized scores of five common household items ${ }^{5}$. Finally, the subjective standard of living measure is an ordinal variable based on the following question: "If you compare the living standard of this household with the average living standard in Chile, would you say that this household is: (1) much lower than average, (2) a bit below average, (3) about average, (4) a bit above average, or (5) much above average?"

The analysis of each standard of living measure (not shown, tables available from the authors) reveals a set of determinants that are similar to those found for vehicle ownership. In every case the parental wealth terms have positive, significant effects net of the other parental 
resource variables (column 1 models). Again, the effects of parental wealth become insignificant upon controlling for the couple's human capital and labor market income. Moreover, in every case, the explanatory power of the model, as judged by the $\mathrm{R}^{2}$ coefficient, increases between two- and three-fold after adding terms for the children's human capital and income to the model, pointing to the presence in Chile of opportunities to acquire education and labor market income apart from the contribution of parental resources.

To summarize: With respect to the consumption measures, our findings show that parental wealth has a substantial impact on the living standards of adult children, but that the effect is largely indirect, operating through parental investments in education and earnings capacity. Also noteworthy--but hardly surprising--is the finding that duration of the union has a significant effect on the various indicators of the couple's living standard, consistent with a process of growth in human capital and earnings. Finally, our results suggest an observation about the workings of the education system and the labor market in Chile, namely that they appear to offer opportunity for upward mobility to children from poor households in which parental resources are insufficient to impart an advantageous starting point in life.

Parental influences on asset ownership. This section examines the determinants of the second dimension of economic well-being, namely asset ownership. Whereas the utility of a consumption item is intimately tied to the use value of goods and services, the value of an asset item extends beyond any possible use value and relates primarily to the beneficial property of "consumption storage" (Spilerman 2000). This feature is especially valuable in Latin America, where variations in the economic cycle can lead to unemployment and subemployment for large segments of the population and where public welfare coverage is limited, leaving many families unprotected and dependent on their own resources in the event of an economic crisis

${ }^{5}$ They are refrigerator, washing machine, telephone, cable TV, and computer. 
(Lustig 2001). In this context, even modest wealth holdings can be crucial to avoiding major discontinuities in consumption expenditures.

The parental resource effects are examined with respect to four asset types--real estate, financial assets (stock, bonds, and mutual funds), business equity, and residential property (excluding primary residence); ownership of each is a dichotomous outcome and logistic regression is utilized. (Due to the complex relationship between parental resources and home ownership, noted earlier, we analyze the home acquisition process separately in the next section.) Analogous to the examination of consumption level, we present a detailed analysis of one measure of the couple's asset ownership--real estate holdings in the present section-followed by a summary of the findings from the other measures. Again, we estimate two models for each asset item. The first presents the total effects of the parental background variables; the second adds the human capital terms and the couple's labor market income to gauge the extent to which the parental resources variables operate indirectly, through returns to human capital investments.

One new consideration: It cannot be assumed that respondent's current income affects the holdings of expensive assets, such as commercial real estate, which, to the extent they were financed by labor market income may have been purchased from savings over several years in the past. Ideally, to assess the extent to which asset holdings come from labor market income-and, indirectly, from parental resource effects through investments in children's education and earnings--we want a measure of respondent's cumulative labor market income in the years prior to the purchase of the item. We lack such a measure and, instead, utilize a proxy based on life 
course accumulations from labor market activity, formulated as the product of a couple's current labor market income and duration of marriage or cohabitation. ${ }^{6}$

Table 5 reports the contribution of the parental terms to real estate ownership. Model 1 reveals that the standard socioeconomic measures of parental resources--father's education and occupational status--do not influence the couple's real estate holdings. Parental wealth, in contrast, has substantial effects, virtually identical in magnitude for the parents of each spouse/partner. The initial finding, then, is that parental wealth matters for real estate ownership, while the other parental resources are of little consequence.

\section{TABLE 5 ABOUT HERE}

Model 2 adds variables for the couple's human capital and for accumulated labor market income over the life course, along with the duration variables and the other controls. Observe first that the cumulative labor market income term is highly significant and has a large impact on the odds of real estate ownership; a doubling of cumulative income would raise the odds by $69 \%$. Husband's age at marriage also contributes to asset ownership; this measure taps career development and, possibly, savings that the husband brought to the marital union. Years of marriage, in comparison, is not significant. This term was introduced as a proxy for savings over the marital course; however, its effect is fully offset by the cumulative income variable, which also reflects duration of the union. This assessment was confirmed by

\footnotetext{
${ }^{6}$ The error in this regressor from mismeasurement would likely depress its effect on the dependent variable. Alternative measures of life course accumulation from labor market activity were considered, such as ones based on estimates of "permanent income"--e.g. the product of husband's occupational status and years of marriage/cohabitation. The substantive findings with such measures were identical to the results presented in the text.
} 
replacing the latter with the term for current income; as expected the duration variable becomes significant and positive.

Of greater relevance is the consequence of the couple's educational attainment and labor market income for the parental wealth effects since these relate to the pathway of parental influence on respondent's asset holdings. The parental wealth terms remain highly significant with their magnitudes reduced in each case by some $20 \%$. It is evident that the bulk of the parental wealth effects on ownership of this particular asset are direct, indicative of parental financial and material transfers to offspring rather than a process of investment in education and subsequent earnings. At the same time the equation $\mathrm{R}^{2}$ is much increased between models 1 and 2, suggesting that labor market income can be an independent means to asset accumulation in Chile, and that children from poor origins have used this route to build real estate holdings. We further emphasize that our estimate of the direct parental transmission is an upper bound, in that a more accurate measure of cumulative labor market income prior to asset acquisition would likely result in a reduction of the parental wealth coefficients in equation 2 .

Analyses of the couple's financial assets, business equity, and residential property ${ }^{7}$ confirm, first of all, that parental wealth is the primary parental resource that influences children's asset holdings, and, second, that direct transfers of resources are an important part of the acquisition process. Regarding the total parental effects (equation 1 models), both parental wealth terms--for the parents of husband and wife--are significant for every asset type; in several instances one of the other parental resource terms is also significant though there is no consistent pattern to those effects. After controls are added for husband's education and cumulative household income (equation 2 models), the net parental wealth effects are reduced, 
though both wealth terms remain significant for each asset type, with the sole exception of husband's parental wealth in the residential property equation; at the same time no other parental resource variable, neither father's education nor occupational status, achieves significance. Again, in the case of each asset type, the term for cumulative labor market income has a strong positive effect and the added $\mathrm{R}^{2}$ from inclusion of this variable is considerable.

To summarize, we find evidence for two different patterns in the effects of parental resources on the economic well-being of children. With respect to the consumption items, it is the case that father's occupational status (a proxy for permanent income), father's education (an indicator of parental values since it is net of occupational status), and parental wealth all have substantial effects on the living standards of offspring. It is also the case that the parental resource terms operate through child's education and, consequently, through labor market income. There is little evidence for direct financial transmission in the determination of the consumption items, probably because the costs associated with acquisition of these items are relatively small. In contrast, with regard to financial, business, and investment assets, it is mainly parental wealth that matters and, further, much of the transmission is direct. At the same time, our analysis suggests that part of the determination of consumption level and asset ownership in the Chilean population--a substantial portion in the case of the consumption items--comes about through schooling and income attainment in ways that are not derivative of parental resources.

\section{A STRUCTURAL EQUATION MODEL (SEM) OF LIVING STANDARDS}

\footnotetext{
${ }^{7}$ The tables for these models are available from the authors.
} 
As an alternative to examining the determination of each consumption and asset item separately, we consider a model of the parental effects on consumption level (living standard) and on asset ownership in which these two constructs are formulated as unobserved, latent variables, with the observed consumption and asset items serving as indicators. This formulation is introduced for two reasons: first, we have argued that the determination process is similar for the items in each construct, which suggests that each can be well-represented by a summary underlying model. Second, the use of latent variables reduces the confounding between life style choice (a preference for particular consumption items) and living standard (a hierarchical measure of well being), in that what is now modeled is the shared variance in a family's consumption expenditures. Similarly, in the case of asset holdings, the SEM estimates tap the breadth of the wealth portfolio rather than ownership of a specific item.

For the examination of the consumption items, we use a MIMIC model (multiple indicators, multiple causes) in which a couple's parental resources, along with labor market income and the controls are viewed as influencing the living standard construct. This unobserved variable, in turn, is identified by its loadings on the several consumption items. The equations for the MIMIC model are (Joreskog and Sorbom 1989, p. 173),

$$
\begin{aligned}
& \underline{Y}=\underline{\lambda} \eta+\underline{\varepsilon} \\
& \eta=\underline{y}^{\prime} \underline{X}+\zeta
\end{aligned}
$$

where $\underline{Y}$ is a vector of indicators of the latent variable $\eta$ (living standard), $\underline{\lambda}$ is a vector of factor loadings relating the indicators to the latent variable, $\underline{X}$ is a vector of the exogenous "causes" of $\eta$, and $\chi$ is a coefficient vector. The $\varepsilon$ 's and $\zeta$ 's are assumed to be mutually uncorrelated. 
The living standard construct is measured by the four consumption indicators: ownership of a vehicle, use of domestic service, ownership of consumer durables, and a subjective evaluation of one's standard of living. All the terms are categorical, with the exception of consumer durables which is continuous, constructed as a sum of z-scores for ownership of five household items. Because of the categorical nature of several of the indicators, estimation is by weighted least squares.

Our intent in this section is not one of building a full model of the parental effects on living standard or asset ownership, which would require a consideration of the determination of the several intervening processes--the fact, for example that the couple's educational attainments and income mediate between parental resources and the outcome variables. Rather, our objective is to use SEM only to extend the formulations in Tables 4 and 5 by having the outcome variables represented by the common variance in the sets of indicator terms. Thus, we treat all the explanatory variables as exogenous and follow the structure of models 1 and 2 of the earlier tables, first estimating the total parental effects on a latent variable, then adding terms for the couple's human capital and labor market income along with the controls.

The results for the consumption items, viewed as indicators of a latent living standard construct, are presented in Table 6. The factor loadings of the indicators are reported in the first four rows; all have strong associations with the latent variable (a standard error cannot be computed for the reference indicator, domestic service). Since the dependent variable is a statistical construct, to facilitate discussion of the relative effects of the explanatory variables, standardized coefficients are reported along with the unstandardized parameter estimates; the former appear in the third column of each model. The total effects of the parental terms (model 1) are consistent with the earlier discussion: all the parental resources, from both husband's and 
wife's families, contribute to the couple's living standard, though we now find more modest effects from the parental wealth terms, as indicated by the standardized estimates.

\section{TABLE 6 ABOUT HERE}

The full equation, which takes into account the couple's human capital and labor market income, is reported as model 2. Again, the results parallel the Table 4 findings; by far the largest contributions to living standard, as indicated by the standardized estimates, come from the couple's education and income variables. Net of these effects, while some of the parental terms--husband's father's education, wife's father's occupation--retain statistical significance, the effects are quite small relative to the couple's own resources. Moreover, since both parental wealth terms are insignificant, there is no evidence of direct financial transfers on behalf of the couple's living standard. In summary, the findings are fairly robust to specification, whether formulated in terms of the consumption components or a latent construct: There are strong parental effects, including parental wealth effects, on the living standard of offspring, but these transmissions operate almost entirely through parental investments in human capital and earnings capacity.

The comparable analysis for the determination of asset ownership is more complex. While our intent is to extend the formulation of Table 5 only by introducing a latent term for asset holdings, we cannot ignore the fact that one of the asset items--business ownership--can be a source of labor market income. Consequently, it is necessary to treat the cumulative income variable, along with asset holdings, as endogenous and introduce terms for the identification of each equation. For this purpose we add "number of inheritances received" to the asset equation; this variable is assumed to not directly affect labor market income. Similarly, we add "husband's occupational status" to the equation for cumulative labor market 
income, as any impact of this term on asset holdings would presumably come through the income variable. This more general SEM model is given by the equations,

$$
\begin{aligned}
& \underline{Y}=\underline{\lambda} \eta+\underline{\varepsilon} \\
& \eta=\beta_{1} Z+\underline{y}_{1} \underline{X}_{1}+\zeta_{1} \\
& Z=\beta_{2} \eta+\underline{x}_{2} \underline{X}_{2}+\zeta_{2}
\end{aligned}
$$

where equation (3) is the measurement model for the latent variable $\eta$ (asset holdings), (4) is the structural equation for the determination of $\eta$, and (5) is the equation for the determination of $\mathrm{Z}$, the endogenous variable for cumulative labor market income. In these equations, $\underline{Y}$ is a vector of indicators of the latent variable $\eta ; X_{1}$ and $X_{2}$ are vectors of exogenous variables. The $\varepsilon$ 's and $\zeta$ 's are assumed to be mutually uncorrelated.

\section{TABLE 7 ABOUT HERE}

The results from the SEM estimation of asset holdings are reported in Table 7. Since the model 1 specification contains only the parental resource terms, it is an immediate generalization of equation (1) of Table 5, with the single indicator model replaced by the factor analytic formulation of asset holdings. The findings with respect to the parental terms indicate that both occupational status (a proxy for income) and wealth contribute to the level of asset holdings, with the wealth terms having a greater effect, as suggested by the standardized estimates.

Adding terms for husband's and wife's educational attainment and cumulative income-our generalization of equation (2) of Table 5--results in equations $2 a$ and $2 b$ for the two endogenous variables. While not central to our interests, we comment first on equation 2a. The findings for the determinants of cumulative labor market income conform to expectations: 
years of marriage has the greatest impact, followed by the human capital terms. Net of these variables, parental occupational status and wealth are significant, with standardized effects that are comparable in magnitude. Note also that there is no evidence of an effect of asset holdings on labor market income, though one of the asset indicators, for business equity, would presumably generate such income. Since business holdings is one of four indicators, its unique contribution to the income variable is diminished in this formulation. A more elaborate SEM model, in which business holdings is uncoupled from the other asset indicators, might well reveal an effect on labor market income, but such a formulation is beyond the intent of the present analysis.

Here, our principal interest is concerned with the determination of asset holdings (equation 2b). By far the largest contribution, in the standardized metric, comes from cumulative labor market income (.634). At the same time, from among the parental terms, only the wealth measures are significant, but their effects are sizeable $(.118 ; .103)$. Moreover, these coefficients underestimate the full contribution of parental wealth because the term for inheritance (.169) also reflects a transfer of parental resources that is net of human capital investments. This part of the direct parental wealth transmission was introduced as a separate regressor in order for the income equation to be identified.

To summarize the findings from the SEM formulations: parental resources make a substantial contribution to both living standards and asset ownership in Chile. In the case of the former, all the parental terms have strong effects and they operate almost entirely through parental investments in the human capital of offspring. In the case of asset ownership, the landscape is radically different. Parental wealth is the dominant resource in terms of influencing respondent's asset ownership. Further, while a considerable portion of the parental effects come through the labor market income of offspring, there also are strong direct parental 
transmissions, as evidenced by the sizes of the remaining parental wealth terms and the inheritance variable.

\section{THE PARTICULAR STATUS OF HOMEOWNERSHIP}

What is the effect of parental resources on homeownership? Earlier, in the discussion of Table 1, we remarked that the ownership pattern for residences was strikingly different in Chile from either the possession of the other asset types or from homeownership in the U.S., in that there is only a modest sensitivity to household income. It was also apparent that the ownership rate in Chile bears little relation to parental wealth (row 9 of Table 3). We now return to this topic and examine in greater detail two aspects of residence ownership: the parental resource effects on the waiting time to ownership and home value.

Waiting time to ownership is estimated using a Cox proportional hazard model (Wooldridge 2002, chap 20), with duration from marriage/cohabitation to the year of first owned home as the "clock" of the process. The Cox model is specified by the equation,

$$
\mathrm{h}(\mathrm{t}, \underline{\mathrm{X}})=\mathrm{h}_{0}(\mathrm{t}) \exp (\underline{\beta} \underline{\mathrm{X}})
$$

where $\mathrm{X}$ is a column vector of parental and respondent characteristics, $\beta$ is a parameter vector, $h_{0}(t)$ specifies the baseline hazard (which is not a function of the explanatory variables), and the left side term is the hazard of entering the state of ownership at time $t$ by a respondent with covariate vector X. Respondents who have never owned by the survey date are treated as rightcensored observations.

Model 1A of Table 8 reports the total parental resource effects. Not unexpectedly in light of the above comments, they are weak; only one term, for the household wealth of wife's parents, has a positive effect and the impact of that variable is modest: a one standard deviation 
shift generates less than a $5 \%$ change in the hazard rate $\left(\mathrm{e}^{[.019 * 2.45]}\right)$. We have, incidentally, no explanation for the negative effect of wife's father's education and doubt its significance in the full population. Thus, for the institutional reasons described earlier, the homeownership decision in Chile does not appear to be resource constrained; at least, it is not the case that parental resources are brought to bear in a substantial way to reduce the waiting time to ownership.

\section{TABLE 8 ABOUT HERE}

We pursue the matter of the determinants of ownership in model $1 \mathrm{~B}$, in which terms have been added for the characteristics of husband and wife, along with a proxy for household income at the time of home acquisition. In regard to the latter, while we know the year of home acquisition, we do not have an income measure for that time point and, for many respondents, "current household income" refers to a time many years after the acquisition of the first home. Since most first homes were obtained within a few years of marriage we base the respondent's income measure, instead, on questions that refer to the first three years of marriage/cohabitation. Specifically, two variables were introduced: A count of the number of members of the couple who were employed full time during most of the first three years, and a term for husband's occupational status in that period, the latter serving as a proxy for early permanent income. $^{8}$

With the inclusion of these terms there no longer is evidence of a direct parental effect on the hazard of ownership. There are, however, clear indications that the couple's own

\footnotetext{
${ }^{8}$ Cases where husband did not have a status score because he was in school or otherwise did not work during the first three years of marriage/cohabitation were retained by means of the introduction of an indicator variable for "husband not in the labor force."
} 
resources influence the ownership decision. Specifically, homeownership comes earlier for older husbands (presumably, their careers are more advanced and incomes are higher) and for ones who were in higher status (and higher income) occupations early in the marriage. Further, a prior marriage/cohabitation by either spouse lengthens the time to ownership, possibly because it may have resulted in a dilution of resources.

An observation worth making is that there is some contradiction between the findings of the two equations. Equation 1B makes clear that financial constraints do, in fact, impede the acquisition of a home. However, equation 1A provides only weak evidence that parents step up to the plate in this circumstance and contribute to the financing of a home purchase by their children. At this point we can provide no clear resolution to this contradiction; but the following material is suggestive: The Chilean survey inquired about respondent's views of the importance of assisting grown children with the purchase of a residence at the time of marriage; only $3 \%$ replied that "this was the responsibility of parents." In an Israeli survey with an identical question, the comparable rate was $45 \%$ (Spilerman 2004). Parental affection for children is unlikely to be different in the two countries, but the institutional arrangements are quite disparate and this may account for the differential response--and for differential rates of parental assistance in the two countries. ${ }^{9}$

What can be said about the current value of acquired homes; do they reflect parental resources? Equations 2A and 2B address this question using a Heckman selection model to correct for the fact that home value is observed only for the subset of respondents who are homeowners. Only the equations for home value are presented in Table 8, the probit selection equations for residence ownership are not shown since they largely replicate the hazard model

\footnotetext{
${ }^{9}$ In Israel, where there is little co-residence with parents, homeownership is tightly linked to parental wealth and parental assistance. See Spilerman (2004) for details.
} 
results. ${ }^{10}$ Model 2A makes clear that there are substantial parental effects on home value; children from higher economic origins are likely to own residences of greater monetary value. According to equation 2B, however, the bulk of the parental transmission is through education and income; ${ }^{11}$ with the introduction of these terms the direct effects of parental wealth are reduced by some $60-70 \%$ from their initial values. The implication, then, is fairly clear: parental resources do matter for home value, but their impact comes largely through parental investments in the human capital of offspring and only secondarily from financial assistance.

As noted in the introduction, the home acquisition process in Chile does not conform to what has been found for the U.S., Western Europe, or Israel (e.g., Hamnett et. al. 1991; Engelhardt and Mayer 1994; Mulder and Smits 1999; Spilerman 2004), in that there is evidence in Chile of only modest direct parental assistance, either to facilitate an acquisition or permit offspring to purchase a residence of greater monetary value. Indeed, the results from the home value equations suggest parental effects that are more in line with the acquisition of consumption items than asset holdings, namely large total parental effects that mainly operate through investments in children's human capital. Clearly, a deeper understanding of the Chilean housing market will be necessary to better comprehend these somewhat counterintuitive findings.

\footnotetext{
${ }^{10}$ For identification purposes five dummy variables for community size were added to the probit equations. The rationale for their inclusion is that communities of different size have characteristically different homeownership rates. A likelihood ratio test for the added terms was highly significant.

${ }^{11}$ Since home value is examined for current residence, the term for cumulative labor market income replaces the estimate of household income in the early marital period. Over the years respondents may have traded up in residence quality or made improvements to the structure, increasing its value. In this circumstance, the cumulative income term provides the appropriate estimate of the availability of funds from the couple's earnings to finance such contributions to home value.
} 


\section{CONCLUSIONS}

Recent trends in Western countries point to a continued erosion in the availability of publicly funded social welfare programs. This development will necessarily heighten the importance of private family resources, both as a protection against the financial consequences

of crisis events such as illness or job loss, and to enhance a family's ability to finance household expenses at particular life stages, especially the retirement period and the years of raising children and facilitating their well-being.

The last matter speaks to issues in the replication of inequality across generations and the possible strengthening of the linkage between parental resources and the economic welfare of offspring. This is an issue of some import in capitalist countries because a basic tenet of fairness in this type of industrial regime is that the disparity in economic outcomes be linked to effort, education, and hard work. To the extent that the determination of life chances is dominated, instead, by the initial conditions of parental resources, the equitable functioning of the system is called into doubt.

The degree of importance of parental resources is an empirical question and the assessment is likely to vary by country, reflecting the availability of public support programs, ease of access to credit, as well as other institutional arrangements. In the present paper we have examined the issue of parental effects with data from Chile, a country with high inequality and a largely privatized social welfare system; in short a setting in which parental resources would likely be consequential for children's outcomes. Our findings support this expectation, but the results are nuanced and vary with the dimension of children's well being. 
Parental resources have strong effects on both the living standard and asset holdings (i.e., wealth) of adult children. Parental education and occupational status are most critical to living standard (as measured by consumption expenditures); parental wealth, in contrast, has the larger impact on the children's asset portfolio. Moreover, the pathway of transmission differs according to the outcome type under consideration: In the case of living standard, the parental effects are largely mediated by children's education and earnings; thus the avenue of transmission is via parental investments in education. With respect to the asset holdings of offspring, much of the transfer is direct and takes the form of financial assistance and inheritances.

At the same time, we find much to be sanguine about, in that there appears to be opportunity in Chile for the acquisition of consumption items and asset holdings apart from the influence of parental resources. This likely is a consequence of state investments over the years in primary and secondary education, as detailed in Spilerman and Torche (2004), which has made schooling accessible to children from poor families. A note of caution is necessary, however. The economic returns to primary and secondary education in Chile have significantly declined in recent decades. In contrast, the returns to tertiary education have grown rapidly, a pattern that helps explain the high concentration of income among the privileged, who have access to university education, and the high inequality in the country (Beyer 2000, Contreras 2002, Duryea and Pages 2002). Thus, unless further public investments are made to facilitate access by the poor to tertiary schooling, the equalizing role that the educational system has traditionally played in Chile might weaken. ${ }^{12}$

\footnotetext{
12 The trend to a widening wage gap between unskilled and skilled workers as a result of increased returns to knowledge is not a Chilean particularity, but a global trend (Heckman 2001; Mincer 1996). The strength and speed of the Chilean case is, however, remarkable.
} 
The findings with respect to homeownership are more complex. In contrast with the other indicators of asset holdings, the home acquisition process appears to be largely detached from parental resources. We have linked this finding to Chilean housing policy, which, beginning in the 1960s and with special vigor since the late 1980s, has provided subsidized access to homeownership, as opposed to rental solutions. The fact that the acquisition of a residence under this program does not involve costs that are unbearable for young couples appears to have reduced the pressure for parental assistance.

If Chilean housing policy is a mediating factor between parental resources and homeownership, this is not the case with respect to home value, for which the parental effects are considerable. Interestingly, these resource effects appear to work mainly though children's education and occupational attainment, rather than taking the form of direct assistance, although the marginal significance of the parental wealth terms (Table 8 , model 2B) provides weak evidence of direct transfers as well.

While the preceding analysis may be helpful to understanding the dynamics of intergenerational financial linkages in Chile, its full value will only emerge in comparisons with other country studies. It is through a comparative strategy that we can best comprehend the interactions between parental resources, institutional arrangements in a country, and the transmission of advantage, and proceed thereupon to develop efficient programs to offset some of the disadvantages associated with poor family origins. 


\section{REFERENCES}

Attias-Donfut, C. and Wolff, F. C. 2003. "The Redistributive Effects of Generational Transfers." In S. Arber and C. Attias-Donfut (eds). The Myth of Generational Conflict: Family and State in Ageing Societies. London: Routledige. Pp. 22-46.

Becker, G. 1981. A Treatise on the Family. Cambridge Mass: Harvard U. Press.

Beyer, H. (2000) "Educacion y Desigualdad de Ingresos: Hacia una Nueva Mirada" (Education and Earnings Inequality: Towards a New Approach). Estudios Publicos 77 (Verano).

Blau, P. and O.D. Duncan (1967) The American Occupational Structure. New York: Free Press.

Boehm, T. and A. Schlottmann. 2001. "Housing and Wealth Accumulation: Intergenerational Impacts” Working Document, Joint Center for Housing Studies, Harvard University.

Contreras, D. (2002) "Explaining Wage Inequality in Chile: Does Education Really Matter?" Santiago: Department of Economics, Universidad de Chile.

Cummings, J. and D. Dipasquale. 2002. "The Spatial Implications of Housing Policy in Chile" in Glaeser, E. and J. Meyer eds. Chile. Political Economy of Urban Development. Cambridge MA: JFK School of Government Harvard University.

Departamento de Estudios MINVU (Research Department, Ministry of Housing and Urban Development Chile). 2004. "Panoramica de la Vivienda Social en Chile: Balance e Imagenes de un Siglo de Politicas Urbanas en Vivienda y Barrio". Santiago: MINVU.

Duncan, O.D., D Featherman and B. Duncan (1972) Socioeconomic Background and Achievement. New York: Seminar Press.

Duryea, S. and C. Pages (2002) "Achieving High Labor Productivity in Latin America: Is Education Enough?" Washington DC: Inter American Development Bank. Mimeographed Document.

Englehardt, G. and C. Mayer. 1994. "Gift for Home Purchase and Housing Market Behavior" New England Economic Review May-June pp 47-58.

Ganzeboom, H., P. de Graaf and D. Treiman. 1992. “A Standard International Socio-Economic Index of Occupational Status". Social Science Research 21: 1-56.

Green, R. and M. White. 1997. "Measuring the Benefits of Homeowning: Effects on Children" Journal of Urban Economics 41: 441-461. 
Guiso, L. and T. Jappelli. 1999. "Private Transfers, Borrowing Constraints and the Timing of Homeownership." Center for Studies in Economics and Finance. University of Salerno. (Unpublished manuscript).

Hamnett, C. M. Harmer, and P. Williams. 1991. Safe as Houses: Housing Inheritance in Britain. London: Paul Chapman.

Heckman, J. (2001) "Policies to Foster Human Capital" Working Paper 2 N1. Joint Center for Poverty Research. Northwestern University/ University of Chicago.

Honaker, J. A., J. G. King, K. Scheve, N. Singh. 2003. Amelia, A Program for Missing Data. Software Manual. Department of Government, Harvard University. Online at http://gking.harvard.edu/stats.shtml

Joreskog, K. and Sorbom, D. 1989. LISREL 7 Users Reference Guide. Chicago: Scientific Software International.

Kennickell,A. M. Starr-McCluer, and B. Surette. 2000. "Recent Changes in U.S. Family Finances: Results from the 1998 Survey of Consumer Finances". Federal Reserve Bulletin, vol. 86 (January 2000), pp. 1-29.

Kohli, M. 2005. "Intergenerational Transfers and Inheritance: A Comparative View." In Meril silverstein, Roseann Giarruso and Vern L. Bengtson (eds.) Intergenerational Relations Across Time and Place. Springer.

Lohr, S. (1999) Sampling: Design and Analysis. Pacific Grove CA: Duxbury Press.

Lustig, N. ed. 2001. Shielding the Poor: Social Protection in the Developing World. Washington D.C: Brookings Institution Press/ IADB.

Mideplan. 2000. Situacion Habitacional en Chile (Housing Situation in Chile). Documento de Trabajo 5. Santiago, Chile: Ministerio de Planificacion.

Mincer, J. (1996) “Changes in Wage Inequality, 1970-1990”. Working Paper 5823, National Bureau of Economic Research. New York, November.

Moser, C. 1998. "The Asset Vulnerability Framework: Reassessing Urban Poverty Reduction Strategies" World Development Vo.26: 1.

Mulder, C. and J. Smits. 1999. "First-Time Home Ownership of Couples: The Effect of Intergenerational Transmission" European Sociological Review 15: 323-337.

Pardo, C. 2000. "Housing Finance in Chile: The Experience in Primary and Secondary Mortgage Financing" Working Document Best Practices Series, Sustainable Development Department Inter-American Development Bank. Washington D.C.: IADB. 
Raczynski, D. 1994. "Social Policies in Chile: Origin, Transformations and Perspectives". Working Paper 4 Democracy and Social Policy Series. Notre Dame Indiana: University of Notre Dame.

Rojas, E. 1999. "The Long Road to Housing Sector Reform: Lessons from the Chilean Housing Experience" Housing Studies 16 (4): 461-483.

Rubin, D. 1987. Multiple Imputation for Nonresponse in Surveys. New York: Wiley.

Sahn, D. and D. Stifel. 2003. "Exploring Alternative Measures of Welfare in the Absence of Expenditure Data." Review of Income and Wealth. 49(4), pp. 463-489.

Spilerman, S. 2000. "Wealth and Stratification Process" Annual Review of Sociology. V. 26.

Spilerman, S. 2004. "The Impact of Parental Wealth on Early Living Standards in Israel" American Journal of Sociology (July).

Spilerman, S. and F. Torche. 2004. "Living Standard Potential and the Transmission of Advantage in Chile". Chapter 8 in E. Wolff ed. What Has Happened to the Quality of Life in the Advanced Industrial Nations. Northampton MA: Edward Elgar.

Torche, F. 2003. Unequal but Fluid: Social Mobility in Chile in a Comparative Perspective. $\mathrm{Ph}$.D. Dissertation, Columbia University.

Wojtkiewicz, R. 1993. "Simplicity and Complexity in the Effects of Parental Structure on High School Graduation". Demography 30, 4: 701-717.

Wolff, E. 2001. "Recent Trends in Wealth Ownership, from 1983 to 1998" in Shapiro, T. and E. Wolff eds. Assets for the Poor: The Benefits of Spreading Asset Ownership. NY: Russell Sage.

Wooldridge, Jeffrey. 2002. Econometric analysis of Cross Section and Panel Data. Cambridge: MIT Press.

World Bank. 1993. "The Housing Indicators Program" Vol. II: Indicator Tables. Washington D.C.: The World Bank.

.2000a. Poverty and Policy in Latin America and the Caribbean. World Bank Technical Paper \# 467. Washington D.C.: World Bank.

.2000b. World Development Indicators. Washington D.C.: World Bank.

Wormald, G. and J. Rozas. 1996. "Microenterprises and the Informal Sector in the Santiago Metropolitan Area." In Tokman, V. and E. Klein (eds.) Regulation and the informal economy: microenterprises in Chile, Ecuador, and Jamaica. Boulder, CO: Lynne Rienner Pubs. 
TABLE 1. DISTRIBUTION OF ASSET OWNERSHIP BY INCOME GROUP, CHILE AND U.S.

\begin{tabular}{|c|c|c|c|c|c|c|c|c|c|c|c|c|c|c|c|}
\hline & \multicolumn{2}{|c|}{$\begin{array}{l}\text { Financial } \\
\text { Assets }^{2}\end{array}$} & \multicolumn{2}{|c|}{$\begin{array}{c}\text { Real } \\
\text { Estate }^{3}\end{array}$} & \multicolumn{2}{|c|}{$\begin{array}{l}\text { Residential } \\
\text { Property }\end{array}$} & \multirow{2}{*}{$\begin{array}{c}\text { Business } \\
\text { Chile U.S. }\end{array}$} & \multicolumn{2}{|c|}{ Vehicle } & \multicolumn{3}{|c|}{$\begin{array}{c}\text { Housing Status-- } \\
\text { Chile }\end{array}$} & \multicolumn{3}{|c|}{ Housing Status--U.S. } \\
\hline $\begin{array}{l}\text { Percentile of } \\
\text { Income }^{1}\end{array}$ & Chile & U.S. & Chile & U.S. & Chile & U.S. & & Chile & U.S. & Own & Rent & $\begin{array}{l}\text { Othe } \\
\mathrm{r}^{5}\end{array}$ & Own & Rent & Other $^{5}$ \\
\hline $20-39.9$ & 1.9 & 26.3 & 3.1 & 6.1 & 4.3 & 6.8 & 11.0 & 16.0 & 81.9 & 68.2 & 10.7 & 21.8 & 55.4 & 40.9 & 3.8 \\
\hline $60-79.9$ & 2.7 & 51.6 & 6.5 & 9.5 & 13.0 & 17.0 & 18.613 .9 & 45.3 & 93.0 & 68.4 & 16.4 & 15.8 & 79.2 & 19.5 & 1.3 \\
\hline $80-89.9$ & 7.1 & 64.2 & 9.1 & 14.1 & 17.0 & 17.7 & 32.218 .8 & 72.1 & 92.8 & 70.5 & 20.0 & 9.6 & 88.4 & 11.0 & 0.6 \\
\hline $90-100$ & 22.0 & 82.2 & 25.0 & 21.1 & 42.5 & 35.5 & $39.5 \quad 31.0$ & 91.9 & 90.0 & 75.0 & 21.4 & 3.7 & 93.0 & 6.3 & 0.7 \\
\hline
\end{tabular}

Sources: Survey of Intergenerational Financial Linkages in Chile, 2003. Survey of Consumer Finances, 1998 for the U.S. Both surveys were weighted to be nationally representative.

1. Percentiles for the Chilean Survey are as follows: (1) Less than 23; (2) 23-39.9; (3) 40-58; (4) 59-82; (5) 83-91; (6) 92-100. Table entries indicate percentiles for the U.S. data.

2. Includes saving bonds, other bonds, publicly traded stocks, and mutual funds.

3. Comprises farm, land, commercial and rental property, and other types of nonresidential real estate.

4. Includes second home, vacation home, time shares, one- to four-family rental property, and other types of residential property.

5. "Other" includes co-residence with parents, relatives or friends, housing as part of job compensation, temporary quarters, and other tenure arrangements. In Chile $58 \%$ of this category consists of co-residence with parents. 
TABLE 2. MEDIAN VALUE OF PRIMARY RESIDENCE FOR HOME OWNERS, BY INCOME CATEGORY, CHILE AND USA

\begin{tabular}{lcccc}
\hline & \multicolumn{2}{c}{ Home Value } & Home Value, relative to low category \\
\cline { 2 - 5 } Income Percentile $^{1}$ & $\begin{array}{c}\text { U.S. } \\
\text { (2001 U.S.\$) }\end{array}$ & $\begin{array}{c}\text { Chile }^{2} \\
\text { (Pesos, in thousands) }\end{array}$ & U.S. & Chile \\
\hline Less than 20 & 59,900 & 10,600 & 1.0 & 1.0 \\
$20-39.9$ & 81,600 & 12,300 & 1.4 & 1.2 \\
$40-59.9$ & 92,500 & 14,400 & 1.5 & 2.4 \\
$60-79.9$ & 119,700 & 21,300 & 2.0 & 2.8 \\
$80-89.9$ & 149,100 & 30,000 & 2.5 & 5.5 \\
$90-100$ & 244,900 & 58,500 & 4.1 & \\
\hline All households & 108,800 & 20,300 & & \\
\hline
\end{tabular}

Source: Survey of Intergenerational Financial Linkages in Chile, 2003; Survey of Consumer Finances 1998 for U.S., adjusted to 2001 dollars. Both surveys are weighted to be nationally representative.

1. Percentiles for the Chilean Survey are as follows: (1) Less than 23; (2) 23-39.9; (3) 40-58; (4) 59-82; (5) $83-91$; (6) 92-100. Table entries indicate percentiles for the U.S. data.

2. As of July 2004, a U.S. dollar equals $\$ 630$ Chilean pesos. 
TABLE 3. DESCRIPTIVE STATISTICS RELATING COUPLE'S LIVING STANDARD TO

PARENTAL WEALTH ${ }^{1}$

\begin{tabular}{|c|c|c|c|c|c|c|}
\hline \multirow[b]{2}{*}{$\begin{array}{l}\text { Measures of Couple's } \\
\text { Frnnnmir W/ll_heino }\end{array}$} & \multicolumn{6}{|c|}{ Parental wealth $^{2}$} \\
\hline & $\begin{array}{l}1= \\
I \text { nwx }\end{array}$ & 2 & 3 & 4 & $\begin{array}{l}5= \\
\text { Hioh }\end{array}$ & $\mathrm{N}$ \\
\hline \multicolumn{7}{|l|}{ Consumption Level } \\
\hline 1. Vehicle Ownership ${ }^{3}$ & 0.30 & 0.40 & 0.40 & 0.50 & 0.61 & 3667 \\
\hline 2. Domestic Service ${ }^{4}$ & 0.04 & 0.08 & 0.11 & 0.14 & 0.31 & 3667 \\
\hline 3. Number of Household Items ${ }^{5}$ & -0.43 & 0.17 & 0.27 & 0.87 & 2.02 & 3648 \\
\hline 4. Subjective Standard of & -0.35 & -0.03 & 0.17 & 0.27 & 0.85 & 3516 \\
\hline \multicolumn{7}{|l|}{ Asset ownership } \\
\hline 5. Financial Assets ${ }^{7}$ & 0.01 & 0.02 & 0.06 & 0.05 & 0.13 & 3656 \\
\hline 6. Business Ownership ${ }^{8}$ & 0.12 & 0.21 & 0.21 & 0.25 & 0.29 & 3667 \\
\hline 7. Real Estate Ownership ${ }^{9}$ & 0.04 & 0.09 & 0.09 & 0.11 & 0.18 & 3660 \\
\hline 8. Residential Property ${ }^{10}$ & 0.08 & 0.12 & 0.12 & 0.18 & 0.23 & 3663 \\
\hline 9. Home Ownership ${ }^{11}$ & 0.66 & 0.65 & 0.65 & 0.66 & 0.63 & 3671 \\
\hline \multicolumn{7}{|l|}{ Human capital/ Household Income } \\
\hline 10. Education of Husband ${ }^{12}$ & 9.04 & 9.89 & 10.28 & 10.83 & 12.87 & 3671 \\
\hline 11. Occup. Status of Husband ${ }^{13}$ & 34.11 & 36.82 & 37.91 & 40.35 & 43.27 & 3586 \\
\hline 12. Labor Market Income ${ }^{14}$ & 322.87 & 419.45 & 436.41 & 572.09 & 930.30 & 3596 \\
\hline
\end{tabular}

Source: Survey of Intergenerational Financial Linkages in Chile, 2003.

1. Entries are for married and cohabitating couples where male head is ages 25-69. All values are for year 2003. 2. Parental wealth is measured as the sum of Z-score from counts of ownership of business equity, real estate,

residential property (excluding primary residence) and financial assets (stock, bonds, mutual funds). The measure combines wealth holdings of both sets of parents. Because a large proportion of parents had zero

or near zero asset holdings the low wealth category contains $60 \%$ of the sample; the remaining categories approximate wealth deciles: (2) $11.7 \%$; (3) $8.5 \%$; (4) $11.2 \%$; (5) $9.4 \%$.

3. Proportion of couples who own one or more vehicles.

4. Proportion of couples who use domestic service

5. Sum of Z-scores from count of ownership of five common household items. 
6. Subjective SOL by respondent is a 5-point ordinal scale: 1=Much below average, ..., $5=$ Much above average.

7. Proportion of couples who own financial assets (stock, bonds, mutual funds).

8. Proportion of couples who own a business (full or part ownership).

9. Proportion of couples who own real estate.

10. Proportion of couples who own residential property.

11. Proportion of couples who are home owners.

12. Number of years of schooling completed.

13. Occupational status coded by International Socioeconomic Status Index scores

(Ganzeboom, et. al 1992).

14. Monthly labor market income of household in Chilean Pesos (thousands). 
TABLE 4. PARENTAL RESOURCE EFFECTS ON VEHICLE OWNERSHIP, CHILE $2003^{1}$

\begin{tabular}{|c|c|c|}
\hline & Model 1 & Model 2 \\
\hline Constant & $-2.247 * * * \quad(0.133)$ & $-10.556^{* * *}(0.434)$ \\
\hline \multicolumn{3}{|l|}{ Husband's Father: } \\
\hline Education $^{2}$ & $0.038 * * * \quad(0.011)$ & $(0.012)$ \\
\hline Occupational status ${ }^{3}$ & $0.021 * * * \quad(0.004)$ & $(0.005)$ \\
\hline Household wealth ${ }^{4}$ & $0.063^{* * *} \quad(0.016)$ & $(0.018)$ \\
\hline \multicolumn{3}{|l|}{ Wife's Father: } \\
\hline Education $^{2}$ & $(0.010)$ & $-0.030^{*}$ \\
\hline Occupational status ${ }^{3}$ & $0.023 * * * \quad(0.004)$ & $(0.005)$ \\
\hline Household wealth $^{4}$ & $0.049^{* *} \quad(0.016)$ & $(0.018)$ \\
\hline Husband's age at marriage ${ }^{5}$ & & $(0.008)$ \\
\hline Years of marriage $^{6}$ & & $0.030 * * * \quad(0.004)$ \\
\hline Husband or wife had previous marriage ${ }^{7}$ & & $0.171 \quad(0.122)$ \\
\hline Husband's education ${ }^{2}$ & & $0.050 * * * \quad(0.015)$ \\
\hline Wife's education ${ }^{2}$ & & $0.029 \quad(0.016)$ \\
\hline Labor market income $(\ln )^{8}$ & & $1.399 * * * \quad(0.073)$ \\
\hline Pseudo- $\mathrm{R}^{2}$ & .092 & .249 \\
\hline $\mathrm{N}$ & 3811 & 3811 \\
\hline$* \mathrm{p}<.05, * * \mathrm{P}<.01, * * * \mathrm{P}<.001$ & & \\
\hline
\end{tabular}

1. Unstandardized coefficients from logistic regression; standard errors in parentheses.

Dependent variable coded 1

if household owns one or more vehicles; 0 otherwise. Results based on multiple imputation with five data sets.

2. Years of schooling completed.

3. Occupational status coded by ISEI status scores (Ganzeboom, et. al 1992).

4. Estimate of parent's wealth holdings. See text for details.

5. Age of husband at time of marriage/ cohabitation.

6. Years of marriage/ cohabitation 
7. Indicator variable coded 1 if either husband or wife had a previous marriage or cohabitation.

8. Ln(household income from labor market activity, in Chilean pesos).

TABLE 5. PARENTAL RESOURCE EFFECTS ON REAL ESTATE OWNERSHIP, CHILE $2003^{1}$

\begin{tabular}{|c|c|c|c|}
\hline & Model 1 & \multicolumn{2}{|c|}{ Model 2} \\
\hline Constant & $-3.103 * * *(0.206)$ & $-9.652 * * *$ & $(0.714)$ \\
\hline \multicolumn{4}{|l|}{ Husband's Father: } \\
\hline Education $^{2}$ & $(0.022)$ & 0.036 & $(0.023)$ \\
\hline Occupational status ${ }^{3}$ & $-0.000 \quad(0.007)$ & -0.011 & $(0.008)$ \\
\hline Household wealth ${ }^{4}$ & $0.104^{* * *}(0.021)$ & $0.087 * * *$ & $(0.022)$ \\
\hline \multicolumn{4}{|l|}{ Wife's Father: } \\
\hline Education $^{2}$ & $(0.020)$ & -0.018 & $(0.022)$ \\
\hline Occupational status ${ }^{3}$ & $(0.006)$ & -0.004 & $(0.007)$ \\
\hline Household wealth ${ }^{4}$ & $0.104 * * *(0.021)$ & $0.075 * * *$ & $(0.022)$ \\
\hline Husband's age at marriage ${ }^{5}$ & \multicolumn{3}{|c|}{$0.037 * *$} \\
\hline Years of marriage $^{6}$ & \multicolumn{3}{|c|}{ †ì.004 } \\
\hline Husband or wife had previous marriage ${ }^{7}$ & \multicolumn{3}{|r|}{$(0.209)$} \\
\hline Husband's education $^{2}$ & \multicolumn{3}{|c|}{0.018} \\
\hline Wife's education ${ }^{2}$ & \multicolumn{3}{|c|}{-0.002} \\
\hline Cumulative labor market income $(\ln )^{8}$ & \multicolumn{3}{|c|}{$0.694 * * *$} \\
\hline Pseudo- $\mathrm{R}^{2}$ & .061 & \multicolumn{2}{|l|}{.122} \\
\hline $\mathrm{N}$ & \multirow[t]{2}{*}{3811} & \multicolumn{2}{|l|}{3811} \\
\hline$* \mathrm{p}<.05, * * \mathrm{P}<.01, * * * \mathrm{P}<.001$ & & & \\
\hline
\end{tabular}

1. Unstandardized coefficients from logistic regression; standard errors in parentheses.

Dependent variable coded 1

if the household owns farm, land, commercial /rental property, or other nonresidential real estate. Results based

on multiple imputation with five data sets.

2. Years of schooling completed. 
3. Occupational status coded by ISEI status scores (Ganzeboom, et. al 1992).

4. Estimate of parent's wealth holdings. See text for details.

5. Age of husband at time of marriage/ cohabitation.

6. Years of marriage/ cohabitation

7. Indicator variable coded 1 if either husband or wife had a previous marriage or cohabitation.

8. Estimate of household's cumulative labor market income since year of marriage/ cohabitation (ln). See text for details.

TABLE 6. STRUCTURAL EQUATI ON MODEL OF LI VING STANDARDS, CHI LE $2003^{1}$

Model 2

Model 1

FACTOR LOADINGS:

Subjective SOL ${ }^{2}$

-. . . 756

Household it ems ${ }^{3}$

$(.095) \quad .750$

Domestic service ${ }^{4}$

$(.065) \quad .884$

Aut 0 ownershi $p^{4}$

$(.046) \quad .790$

1. 000

-

$3.086 * * *$

(.111)

1. $198 * * *$

1.048

1. $045^{* * *}$

1.033

$3) \quad .774$

.747

1.000

REGRESSORS:

Husband's Father:

$$
\text { Education }
$$

$(.004) \quad .054$

Occupational status ${ }^{5}$

$(.002) \quad .008$

Household weal th ${ }^{6}$

$(.005) \quad .015$

Wife's Father:

$\begin{array}{llll}.033 * * * & (.004) & .183 & .011 * * \\ .010 * * * & (.002) & .165 & .001 \\ .029 * * * & (.006) & .086 & .006\end{array}$


Education

$(.004) \quad-.022$

occupational status ${ }^{5}$

$(.001) \quad .046$

Household weal th ${ }^{6}$

$(.006) \quad .004$

Husband's age at marr.

$(.002) \quad .048$

Years of marriage

$(.001) \quad .224$

Husband or wife had

a prior marriage

$(.037)-.010$

Husband's education

$(.005) \quad .182$

Wife's education

$(.005) \quad .126$

Labor market income $(I n)^{8}$

$(.025) \quad .614$
$.018 * * * \quad(.004) \quad .099 \quad-.005$

$.013 * * * \quad(.001) \quad .201 \quad .004 * *$

$.032 * * * \quad(.006) \quad .095 \quad .001$
$.007 * * *$

$.020 * * *$

$-.026$

$.044 * * *$

$.031 * * *$

$.680 * * *$

$* p<.05, * * p<.01, * * * p<.001$

$R^{2}$

N

Fit Indices:

CFI

RMSEA
.345

3811

.993
.754

3811

.940

$.017 \quad .034$

1. Results based on multiple imputation with five data sets.

For each model

the column 1 entries are unstandardized coefficients, column 2 contains

standard errors and column 3 reports the standardized est i mates.

2. Five category subjective scale.

3. Sum of $z$-scores for ownership of five common household durables.

4. Bi nary term for ownership of the item.

5. Occupational status coded by ISEI status scores. 
6. Esti mate of parent's wealth holdings. See text for details. 7. Dummy term, coded 1 if either partner had a prior marriage/cohabitation.

8. Ln(current household income from labor market activity, in Pesos). 
TABLE 7. STRUCTURAL EQUATI ON MODEL OF ASSET HOLDI NGS, CHI LE $2003^{1}$

Model 1

Model $2 b$

ASSET HOLDI NGS
Mbdel 2a

CUMULATI VE I NCOME

\section{FACTOR LOADI NGS: 2 \\ Fi nanci al assets -. .507}

Resi denti al prop.

1. $315^{* * *}(.170) \quad .646$

Real est at e

1. 386*** (. 183) . 676

Busi ness ownership

$.983 * * *$ (.131) .498

REGRESSORS:

Cumul at i ve i ncome ${ }^{3}$

(.051) . 634

Asset hol di ngs ${ }^{4}$

Husband's Father:

Educat i on

Occupat i onal stat us ${ }^{5}$

(. .002) -. 019
1. 000
-. .566
1. $259 * * * \quad(.149) \quad .699$
1. $395 * * * \quad(.165) \quad .766$
$.701 * * * \quad(.098) \quad .404$

1. 000
$319 * * *$

$-.025 \quad(.098)-.013$

$.010 \quad(.005) \quad .077$

$005 * *$

$(.002) \quad .113$
.003

(.004) .012

$004 * *$

(.001)

047 


\begin{tabular}{|c|c|c|c|c|c|c|c|}
\hline Househol d weal $\mathrm{th}^{6}$ & $.039 * * *$ & $(.007)$ & .166 & $.023 * * *$ & $(.006)$ & .054 & $.025 * * *$ \\
\hline$(.006) \quad .118$ & & & & & & & \\
\hline \multicolumn{8}{|l|}{ Wfe's Fat her: } \\
\hline \multicolumn{8}{|l|}{$(.005)-.028$} \\
\hline Occupat i onal st at us ${ }^{5}$ & $.005 * *$ & $(.002)$ & .107 & $.005 * * *$ & $(.001)$ & .063 & -.001 \\
\hline \multicolumn{8}{|l|}{$(.001)-.014$} \\
\hline \multicolumn{4}{|l|}{$\begin{array}{l}\text { Husband's age at Marr. } \\
(.003) \quad .071\end{array}$} & $.008^{* * *}$ & $(.002)$ & .048 & $.006 *$ \\
\hline \multicolumn{4}{|l|}{ Years of Marriage } & $.059 * * *$ & $(.002)$ & .636 & $-.006 *$ \\
\hline$(.003)-.127$ & & & & & & & \\
\hline \multicolumn{8}{|l|}{ Husband or wife had } \\
\hline \multirow{2}{*}{\multicolumn{4}{|c|}{$\begin{array}{l}\text { Wf } f e^{\prime} s \text { educat } i \text { on } \\
(.006)-.003\end{array}$}} & $.055 * * *$ & $(.005)$ & .208 & -.001 \\
\hline & & & & & & & \\
\hline \multicolumn{4}{|l|}{$\begin{array}{l}\text { Husband's occup. stat us }{ }^{5} \\
\text { I nherit ances }\end{array}$} & $021 * * *$ & $(.001)$ & .285 & $.284 * * *$ \\
\hline
\end{tabular}

$* \mathrm{p}<05, \quad * * \mathrm{p}<01, \quad * * * \mathrm{p}<001$

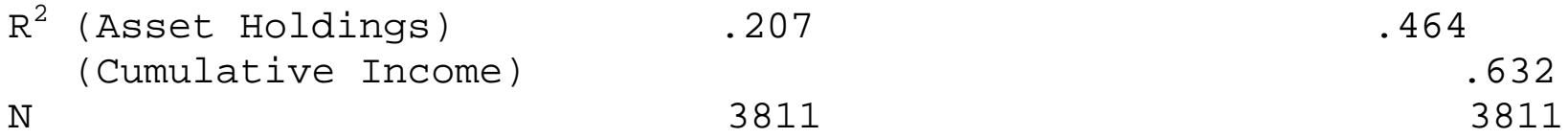


Fi t I ndi ces:

$\begin{array}{lll}\text { CFI } & .932 & .978 \\ \text { RMSEA } & .022 & .025\end{array}$

1. Results based on milti ple i mputation with five data sets. For each model the col um 1 ent $r i$ es are unstandardi zed coeffici ents, col um 2 contai ns standard errors and col umm 3 reports the standardi zed esti mates.

2. Bi nary termfor ounership of each asset item

3. Esti mate of househol d's cumal ative l abor market i ncome si nce marri age (l n).

4. I at ent variable.

5. Occupati onal status coded by I SEl stat us scores.

6. Est i mate of parent's wealth hol dings. See text for details.

7. Dummy term coded 1 if ei ther partner had a pri or marri age/cohabitation.

8. Number of i nheritances by both members of couple. 
TABLE 8. PARENTAL RESOURCE EFFECTS ON ACQUISITION OF FIRST HOME AND VALUE OF

CURRENT HOME, CHILE $2003^{1}$

\begin{tabular}{|c|c|c|c|c|}
\hline & \multicolumn{2}{|c|}{ First Home--Hazard ${ }^{2}$} & \multicolumn{2}{|c|}{ Value of Current Home ${ }^{3}$} \\
\hline & Model 1A & Model 1B & Model 2A & Model 2B \\
\hline \multicolumn{3}{|l|}{ Constant } & $\begin{array}{l}15.807 * * * \\
(0.062)\end{array}$ & $\begin{array}{l}10.706^{* * * *} \\
(0.178)\end{array}$ \\
\hline \multicolumn{5}{|l|}{ Husband's Father: } \\
\hline Education $^{4}$ & 0.007 & 0.004 & $0.033^{* * *}$ & $0.010^{* *}$ \\
\hline Occupation $^{5}$ & 0.001 & -0.002 & $0.008 * * *$ & 0.002 \\
\hline Household & 0.001 & -0.007 & $0.045^{* * *} \quad(0.008)$ & $0.014 *$ \\
\hline \multicolumn{5}{|l|}{ Wife's Father: } \\
\hline Education $^{4}$ & $-0.015 * *$ & $-0.019 * *$ & $0.039 * * * \quad(0.006)$ & $0.009 *$ \\
\hline Occupation $^{5}$ & 0.003 & -0.001 & $0.007 * * * \quad(0.002)$ & 0.001 \\
\hline Household & $0.019^{* *}$ & 0.012 & $0.029 * * * \quad(0.007)$ & $0.013^{*}$ \\
\hline \multicolumn{2}{|c|}{ Husband--age at marriage ${ }^{7}$} & $0.014 * * *$ & & $0.025^{* * *}$ \\
\hline \multicolumn{2}{|c|}{ Years of marriage $^{8}$} & & & $0.013 * * *$ \\
\hline \multicolumn{2}{|c|}{ Previous marriage $^{9}$} & $-0.239 * * *$ & & -0.055 \\
\hline \multicolumn{2}{|l|}{ Husband's education ${ }^{3}$} & -0.008 & & $0.026^{* * *}$ \\
\hline \multicolumn{2}{|c|}{ Wife's education ${ }^{3}$} & 0.001 & & $0.026 * * *$ \\
\hline \multicolumn{2}{|c|}{ No. of spouses employed, early in } & 0.027 & & \\
\hline \multicolumn{2}{|c|}{ Husband did not work, early in } & $-0.270^{*}$ & & \\
\hline \multicolumn{2}{|c|}{ Husband's occupation, early in } & $0.012 * * *$ & & \\
\hline \multicolumn{2}{|c|}{ Cumulative labor market } & & & $0.440 * * *$ \\
\hline \multicolumn{2}{|l|}{ Lambda } & & $\begin{array}{c}-0.873 * * * \\
(0.024)\end{array}$ & $\begin{array}{c}0.112 \\
(0.068)\end{array}$ \\
\hline \multirow{2}{*}{$\begin{array}{l}\text { LR Chi Sq. (N) } \\
\text { W/ald rhi } \mathrm{C}_{r} \\
\mathrm{~N} \\
{ }_{\mathrm{p}}<.05, * * \mathrm{P}<.01, * * * \mathrm{P}<\end{array}$} & $13.08(6)$ & $89.72(13)$ & \multirow[b]{2}{*}{$\begin{array}{l}786)(6) \\
3811\end{array}$} & \\
\hline & 3688 & 3688 & & $\begin{array}{l}30102(17) \\
3811\end{array}$ \\
\hline
\end{tabular}

1. Results based on multiple imputation with five data sets.

2. Cox proportional hazard model of duration from marriage/ cohabitation to first home ownership. Residences acquired before, but within five years of the union were treated as acquired in first year of marriage/cohabitation.

Observation was deleted if the residence was acquired more than five years before the union. Respondents who have not owned a home by the survey date are treated as right-censored observations. 
3. Heckman Selection Model, estimated using Full Information Maximum Likelihood.

Dependent variable is $\ln$ (home value in Chilean pesos). Probit selection equation for home ownership (not shown) includes community size variables for identification.

4. Years of schooling completed.

5. Occupational status coded by ISEI status scores (Ganzeboom, et. al 1992).

6. Estimate of parent's wealth holdings. See text for details.

7. Age of husband at time of marriage/ cohabitation.

8. Years of marriage/ cohabitation

9. Indicator variable coded 1 if husband or wife had a previous marriage or cohabitation.

10. Number of spouses who worked full time during first three years of marriage/ cohabitation

11. Indicator variable coded 1 if husband not in labor force (full or part-time) during first three years of marriage/ cohabitation.

12. Estimate of cumulative income from labor market activity since time of marriage/ cohabitation, in Chilean Pesos (ln). 
TABLE A-1. DESCRIPTIVE STATISTICS FOR VARIABLES IN THE ANALYSIS, SURVEY

OF INTERGENERATIONAL FINANCIAL LINKAGES, CHILE $2003^{1}$.

Variable $\quad$ Mean ${ }^{\text {Standard }}$ Deviation N

Husband's Parents:

Father's Education

Father's Occupation ${ }^{2}$

6.09

4.81

3223

Parents' Wealth ${ }^{3}$

$-.01$

32.11

$\begin{array}{ll} & 13.59 \\ 2.46 & 3730\end{array}$

3301

Wife's Parents:

Father's Education

Father's Occupation ${ }^{2}$

6.29

4.70

3244

Parents' Wealth ${ }^{3}$

31.80

$-.04$

$2.45 \quad 3741$

3326

Couple:

Age of Husband at Marriage

Years of Marriage

26.01

6.49

3737

Either member of couple had

Previous marriage/cohabitation

Husband's Years of Schooling

.18

3804

Wife's Years of Schooling

Occupational Status, $2003^{2}$

9.56

9.88

37.05

Ln(Labor Market Income) ${ }^{4}$

5.63

Ln(Cumulative Labor Mkt. Income)

Ownership of Durables ${ }^{5}$

Vehicle Ownership

Use of Domestic Service

Subjective $\mathrm{SOL}^{6}$

) 8.59

Financial Assets Ownership

.38

.13

.09

Business Ownership

2.86

.04

.17

Real Estate Ownership

Residential Property Ownership

Home Ownership

.07

.66

.11

Years from marriage to

first home ownership

Ln(home value) ${ }^{7}$

$\begin{array}{cc} & 9.80 \\ 16.31 & 97\end{array}$

.47

.39

4.13

3807

3811

4.01

$14.13^{3806} 3722$

$.90 \quad 3701$

$\begin{array}{llll} & 1.05 & 3694 \\ .39 & 3.34 & 3788\end{array}$

No. spouses employed, early marr.

Husband's occupation, early marr. ${ }^{2}$

1.23

35.99

.48

3807

3807

3808

$\begin{array}{ll}.19 & 3794 \\ .38 & 3807\end{array}$

.38

.26

$.32 \quad 3802$

3811

8.09

2477

.54

3809

$14.39 \quad 3675$

1. Sample restricted to households with head aged 25-69 ( $\mathrm{N}=3811)$. Unweighted estimates reported. 
2. ISEI status score (Ganzeboom et. al. 1992).

3. Sum of Z-scores from count of ownership of financial assets, business equity, residential property (excluding primary residence) and real estate.

4. Household's monthly income from labor market activity, in Chilean pesos (ln).

5. Sum of Z-scores from count of ownership of the following household items: refrigerator, washing machine, telephone, cable TV, and computer.

6. 5-point ordinal variable that compares household standard of living with average standard of living of Chilean households.

7. Estimate by respondent in Chilean Pesos. Calculation is for homeowners.

\section{Recent ISERP Working Papers}

04-01: "Reducing Bias in Treatment Effect Estimation in Observational Studies Suffering from Missing Data," Jennifer Hill, International and Public Affairs, Columbia University

04-02: "Production Markets Broker Upstream to Downstream, balancing their volume and quality sensitivities to firms through an oriented market profile of signals," Harrison C. White, Sociology, Columbia University

04-03: "Measuring Economic Disadvantage During Childhood: A Group-Based Modeling Approach," Robert L. Wagmiller, Jr., Sociology, Columbia University

04-04: "Policymaking and Caseload Dynamics: Homeless Shelters," William McAllister, ISERP, and Gordon Berlin, Columbia University

04-05: "Fresh Starts: School Form And Student Outcomes," Christopher Weiss, ISERP, Columbia University and Peter S. Bearman, ISERP, Columbia University

03-01: “The Plasticity of Participation: Evidence From a Participatory Governance Experiment,” Shubham Chaudhuri, Economics, Columbia University, and Patrick Heller, Sociology, Brown University

03-02: "Factional Politics and Credit Networks in Revolutionary Vermont," Henning Hillmann, Sociology, Columbia University

03-03 “ 'Active Patients' in Rural African Health Care: Implications for Welfare, Policy and Privatization," Kenneth L. Leonard, Economics, Columbia University

03-04 "Living at the Edge: America's Low-Income Children and Families," Hsien-Hen Lu, Public Health, Columbia University, Julian Palmer, Younghwan Song, Economics, Union College, Mary Clare Lennon, Public Health, Columbia University, Lawrence Aber, Public Health, Columbia University

02-03 "Link, Search, Interact: The Co-Evolution of NGOs and Interactive Technology," Jonathan Bach, Center on Organizational Innovation, Columbia University and David Stark, Center on Organizational Innovation, Columbia University 
02-04 "Chains of Affection: The Structure of Adolescent Romantic and Sexual Networks," Peter Bearman, Institute for Social and Economic Research and Policy, Columbia University, James Moody, Sociology, Ohio State, Katherine Stovel, Sociology, University of Washington

02-05 "Permanently Beta: Responsive Organization in the Internet Era," Gina Neff, Center on Organizational Innovation (COI), Columbia University, and David Stark, Center on Organizational Innovation (COI), Columbia University 
02-06 "Negotiating the End of Transition: A Network Approach to Political Discourse Dynamics, Hungary 1997,” Balázs Vedres, Columbia University, Péter Csigó, Ecole des Hautes Etudes en Sciences Sociales

For copies of ISERP Working Papers visit http://www.iserp.columbia.edu/research/working_papers/ write to iserp@columbia.edu or call 212-854-3081

\author{
ADMINISTRATION \\ Peter Bearman, Director \\ Kathryn Neckerman, Associate Director \\ Leslie Wright, Assistant Director \\ Institute for Social and Economic \\ Research and Policy \\ Columbia University \\ International Affairs Building \\ 420 West 118 Street, $8^{\text {th }}$ Floor \\ Mail Code 3355 \\ New York, NY 10027 \\ telephone: 212-854-3081 \\ facsimile: 212-854-8925 \\ e-mail: iserp@columbia.edu \\ URL: http://www.iserp.columbia.edu
}




\section{EDITORIAL BOARD}

Karen Barkey, Sociology

Peter Bearman, Sociology/ISERP

Alan Brinkley, History

Charles Cameron, Political Science

Alessandra Casella, Economics

Ester Fuchs, Political Science/SIPA

John Huber, Political Science

Ira Katznelson, Political Science/History

Herbert Klein, History

Mary Clare Lennon, Public Health

Mahmood Mamdani, Anthropology

Marianthi Markatou, Statistics

William McAllister, ISERP

Kathryn Neckerman, ISERP

Richard Nelson, Business/SIPA

Elliot Sclar, Architecture, Planning and

Preservation/SIPA

Seymour Spilerman, Sociology

Charles Tilly, Sociology

Harrison White, Sociology 